\title{
Utilization of whole barley grain by mature ewes depending on forage type and concentrate-to-forage ratio in the diet
}

\author{
Z.M. Kowalski ${ }^{1}$ and R.M. Tait ${ }^{2}$, \\ 1 Department of Animal Nutrition, Agricultural University of Cracow, \\ Al. Mickiewicza 24/28, 30-059 Kraków, Poland \\ 2 Department of Animal Science, University of British Columbia, Vancouver, Canada
}

(Received 2 November 1992; accepted 14 December 1992)

\begin{abstract}
Digestion trials were carried out using 16 mature ewes fed diets based on grass or lucerne hay supplemented with 25 or $40 \%$ of either whole or crushed barley grain. The amount of whole grain voided in faeces was also evaluated. The study was conducted in two repeated Latin squares design separately for each type of hay, with treatments being two physical forms of grain and two concentrate-to-forage ratios.

Except for a slight decrease in dry matter and $\mathrm{N}$ digestibility in lucerne hay based diets, the physical form of grain did not affect DM and ADF digestibility or $\mathrm{N}$ balance, irrespective of the concentrate-to-forage ratio $(P>0.05)$. The amount of whole grain voided in faeces was $4.7-10.2 \%$, however considerable variation among ewes was observed. An increase in the level of grain in the diet from 25 to $40 \%$ increased DM digestibility ( $P<0.01$ ), whilst the grain level had no effect on ADF digestibility. $\mathbf{N}$ balance was improved by increasing the level of grain only when grass hay diets were fed.

The results of this study show that, at levels up to $40 \%$ in the diet, whole barley grain can be effectively utilized by mature ewes fed hay based diets.
\end{abstract}

KEY WORDS: grass, lucerne hay, grain, physical form, digestibility, $\mathrm{N}$ balance

\section{INTRODUCTION}

It is well recognized that whole grain can be effectively utilized by lambs (Ørskov, 1981; Tait and Beames, 1988). However, due to a larger reticulo-omasal orifice in mature sheep, feeding whole grain may increase the proportion of whole grain being voided in faeces. On the other hand, processed grain can negatively affect the environment in the rumen and through a decrease in $\mathrm{pH}$, can lower intake and digestibility of fibre (Ørskov and Fraser, 1975). Grain processing itself also increases costs of feeding.

In typical sheep feeding practice in Poland, concentrates are provided as supplements to forages, including hay, straw or grass silages. There is some 
evidence that the type of forage can influence the utilization of whole grain by mature sheep (Orr and Treacher, 1984; Tait et al., 1985; Vipond et al., 1985; Chestnutt, 1990), but more information is needed, particularly regarding the ratio of concentrate-to-forage in the diet. The digestibility of crude fibre together with forage dry matter intake are usually reduced by increasing the proportion of concentrates in the diet (Uden, 1984). Little is known about the interaction between the physical form of the grain and its level in the diet on nutrient utilization by mature sheep.

The present study was designed to investigate the effect of either whole or crushed barley grain when used as either 25 or $40 \%$ of the diet dry matter on digestibility and $\mathrm{N}$ balance in mature ewes. Sheep were offered diets based on two different quality forages: timothy (Phleum pratense) or lucerne (Medicago sativa) hay.

\section{MATERIAL AND METHODS}

Sixteen mature non-pregnant Dorset ewes (average $63 \mathrm{~kg}$ liveweight) were individually fed either grass ( 8 ewes) or lucerne hay ( 8 ewes). The hays were chopped to a length of approximately $30 \mathrm{~mm}$. Ewes were also offered whole (W) or crushed (C) barley grain in the amount of 25 or $40 \%$ of the diet dry matter. Feeds were given in fixed amounts of approximately $1100 \mathrm{~g}$ and $1250 \mathrm{~g}$ of dry matter for the grass and lucerne hay diets, respectively. These levels were approximately $90 \%$ of to appetite intake and this level was adopted to minimize feed refusals. Mean dry matter intakes for both types of hay are presented in Table 1.

TABLE 1

Mean dry matter intake $(\mathrm{g} /$ day $)$

\begin{tabular}{llcccc}
\hline \multicolumn{1}{c}{ Treatments } & Hay & Barley grain & Total & Forage : Grain \\
\hline Grass hay & & & & & \\
& $25 \mathrm{~W}^{1}$ & 794.4 & 273.2 & 1067.6 & $74.4: 25.6$ \\
& $25 \mathrm{C}^{2}$ & 795.5 & 270.2 & 1065.7 & $74.6: 25.4$ \\
& $40 \mathrm{~W}$ & 644.2 & 438.4 & 1082.6 & $59.5: 40.5$ \\
& $40 \mathrm{C}$ & 643.0 & 431.7 & 1074.7 & $59.8: 40.2$ \\
Lucerne hay & & & & \\
& & & & & \\
& $25 \mathrm{~W}$ & 928.6 & 319.3 & 1247.9 & $74.4: 25.6$ \\
& $25 \mathrm{C}$ & 316.2 & 1250.0 & $74.7: 25.3$ \\
& $40 \mathrm{~W}$ & 746.3 & 504.6 & 1250.9 & $59.7: 40.3$ \\
& $40 \mathrm{C}$ & 746.9 & 510.7 & 1257.6 & $59.4: 40.6$ \\
\hline
\end{tabular}

$1-25 \%$ of the diet, whole grain

${ }^{2}-25 \%$ of the diet, crushed grain 
The ewes were assigned randomly to treatments in two repeated Latin squares design, separately for each type of hay. In the square, treatments consisted of two physical forms of grain and two levels of it in the diet. The ewes were housed in individual pens during a 10-day adaptation period which was followed by 10 days of total faecal and urine collection. During the collection period the ewes were kept in individual metabolic cages. Faeces were weighted daily and two aliquots were taken for chemical analysis and for the determination of the amount of grain voided in faeces. Samples were stored at $-20^{\circ} \mathrm{C}$ until analysis. Separation of the intact grain was carried out on a bulk sample from the whole period; faeces were washed over a sieve of $1.5 \mathrm{~mm}$ diameter. Dry matter content of separated grain was determined by drying in a forced-draught oven at $50^{\circ} \mathrm{C}$ for 48 hours.

Feeds, faeces and urine conserved with $0.1 \mathrm{n} \mathrm{H}_{2} \mathrm{SO}_{4}$ were analysed using standard procedures for DM and N (AOAC, 1975) and for acid detergent fibre (ADF) (Goering and Van Soest, 1970).

The data were subjected to analysis of variance for repeated Latin squares, with results being analysed as a $2 \times 2$ factorial design for main effects of physical form and level of grain in the diet, together with their interaction. Statistical analysis were carried out separately for each type of hay (Steel and Torrie, 1960).

\section{RESULTS}

The chemical composition of hays and barley grain used in the experiment is given in Table 2 . The grass hay was of low quality containing only $6 \%$ of CP and

TABLE 2

Chemical composition of feeds

\begin{tabular}{lrrrr}
\hline & \multicolumn{2}{c}{ Hay } & \multicolumn{2}{c}{ Barley grain } \\
& grass & lucerne & whole & crushed \\
\hline Crude protein $(\mathrm{g} / \mathrm{kg} \mathrm{DM})$ & & & & 128.3 \\
ADF $(\mathrm{g} / \mathrm{kg} \mathrm{DM})$ & 60.0 & 161.6 & 127.8 \\
& 408.0 & 299.8 & 82.0 & 74.1 \\
\hline
\end{tabular}

over $40 \%$ ADF. Crushing of barley grain did not change its $\mathrm{CP}$ content, but silghtly lowered the ADF content (av. 10\%).

The results of the digestibility and $\mathrm{N}$ utilization studies are given in Table 3. With the grass hay diets, the physical form of grain had no effect on DM, ADF and $\mathrm{N}$ digestibility and $\mathrm{N}$ balance. Increasing the level of grain in the diet from 25 to $40 \%$ significantly increased DM digestibility $(\mathrm{P}<0.01$ ), whilst the level of grain had no effect on ADF digestibility. The higher level of grain also resulted in increases in $\mathrm{N}$ intake, apparent digestibility of $\mathrm{N}$, urinary $\mathrm{N}$ output, retained 
The effect the physical form of grain and level of grain in the diet on digestibility and $\mathrm{N}$ utilization

\begin{tabular}{|c|c|c|c|c|c|c|c|c|}
\hline & \multicolumn{4}{|c|}{ Treatments } & \multirow[b]{2}{*}{ SEM } & \multicolumn{3}{|c|}{ Significance of effect } \\
\hline & $25 \mathrm{~W}$ & $25 \mathrm{C}$ & $40 \mathrm{~W}$ & $40 \mathrm{C}$ & & form & level & interaction \\
\hline \multicolumn{9}{|l|}{ Grass hay diets } \\
\hline Dry matter digestibility & 0.627 & 0.644 & 0.674 & 0.667 & 0.0047 & & $* *$ & * \\
\hline ADF digestibility & 0.507 & 0.507 & 0.517 & 0.480 & 0.0074 & & & \\
\hline Total $\mathrm{N}$ intake (g/day) & 13.2 & 13.1 & 15.4 & 15.2 & 0.23 & & $* *$ & \\
\hline $\mathrm{N}$ digestibility & 0.572 & 0.588 & 0.619 & 0.614 & 0.0077 & & $* *$ & \\
\hline Urine $N$ output (g/day) & 5.3 & 5.9 & 5.4 & 6.4 & 0.20 & & & \\
\hline Retained N (g/day) & 2.0 & 1.8 & 4.1 & 2.9 & 0.28 & & $* *$ & \\
\hline Retained $\mathrm{N} \%$ of $\mathrm{N}$ intake & 15.3 & 13.6 & 26.4 & 18.9 & 1.82 & & * & \\
\hline Retained $\mathrm{N} \%$ of $\mathrm{N}$ absorbed & 26.6 & 22.8 & 42.7 & 30.6 & 3.01 & & $*$ & \\
\hline \multicolumn{9}{|l|}{ Lucerne hay diets } \\
\hline Dry matter digestibility & 0.714 & 0.732 & 0.738 & 0.748 & 0.0039 & $*$ & $* *$ & \\
\hline ADF digestibility & 0.515 & 0.516 & 0.499 & 0.504 & 0.0063 & & & \\
\hline Total $\mathrm{N}$ intake (g/day) & 30.3 & 30.6 & 29.6 & 29.5 & 0.17 & & $* *$ & \\
\hline $\mathrm{N}$ digestibility & 0.753 & 0.777 & 0.755 & 0.767 & 0.040 & ** & & \\
\hline Urine $N$ output ( $\mathrm{g} /$ day) & 18.4 & 17.9 & 16.2 & 17.6 & 0.40 & & ** & \\
\hline Retained N (g/day) & 5.1 & 5.9 & 6.2 & 5.0 & 0.39 & & & \\
\hline Retained $\mathrm{N} \%$ of $\mathrm{N}$ intake & 16.6 & 19.3 & 20.9 & 16.9 & 1.30 & & & \\
\hline Retained $\mathrm{N} \%$ of $\mathrm{N}$ absorbed & 21.9 & 24.7 & 27.7 & 22.1 & 1.67 & & & \\
\hline
\end{tabular}

${ }^{*} \ldots \mathrm{P}<0.05,{ }^{* *} \mathrm{P}<0.01$ 
$N(P<0.01)$ and retained $N$ as a percentage of $N$ intake and $N$ absorbed $(\mathrm{P}<0.05)$. With lucerne hay diets, feeding whole barley grain significantly reduced DM $(P<0.05)$ and $N$ digestibility $(P<0.01)$, but did not affect ADF digestibility and other $\mathrm{N}$ balance parameters. Increasing the proportion of grain in the lucerne based diet significantly increased $\mathrm{DM}$ digestibility $(\mathrm{P}<0.01)$ and lowered the amount of $\mathrm{N}$ excreted in urine $(\mathrm{P}<0.01)$, with other parameters being unaffected.

The amount of intact grain voided in the faeces was 10.2 and $6.4 \%$ for the grass hay diets supplemented by 25 and $40 \%$ of whole barley grain, respectively (Table 4). With the lucerne hay diets the results were 8.1 and $4.7 \%$. In each

TABLE 4

Whole grain voided in faeces

\begin{tabular}{|c|c|c|c|}
\hline & \multirow{2}{*}{$\begin{array}{c}\text { Grain DM intake } \\
\text { g/day }\end{array}$} & \multicolumn{2}{|c|}{ Grain voided in the faeces } \\
\hline & & $\mathrm{g}$ of $\mathrm{DM} /$ day & $\%$ of intake \\
\hline \multicolumn{4}{|l|}{ Grass hay diets } \\
\hline $25^{1}$ & $272.7(0.91)^{2}$ & $27.8 \quad(6.28)$ & $10.2 \quad(2.34)$ \\
\hline 40 & $438.6 \quad(1.03)$ & $25.7 \quad(6.85)$ & $6.4 \quad(1.39)$ \\
\hline \multicolumn{4}{|l|}{ Lucerne hay diets } \\
\hline 25 & $310.3 \quad(0.95)$ & $26.0 \quad(6.32)$ & $8.1 \quad(2.00)$ \\
\hline 40 & $510.7 \quad(1.43)$ & $23.9 \quad(5.46)$ & $4.7 \quad(1.13)$ \\
\hline
\end{tabular}

1 - level of grain in the diet $(\%)$

2 - (Standard error)

treatment considerable variation among ewes was observed and differences between means were not statistically significant.

\section{DISCUSSION}

Results of this study indicate that whole barley grain, when fed as a supplement to grass or lucerne hay, can be effectively utilized by mature ewes. It confirms earlier observations obtained with hay based diets (Mould et al., 1983; Tait et al., 1985; Chestnutt, 1990). The type of hay seems to have no effect on the efficiency of the utilization of whole grain, except for a slightly lower DM and $\mathrm{N}$ digestibility when whole grain was used to supplement lucerne hay. It is possible that both hay diets underwent similar rumination processes which could be responsible for whole grain mastication. Toland (1978) found that in cattle chewing played a dominant role during rumination in the process of digestion of whole oats grain, and was more important than rumen fermentation. Recently, Chestnutt (1990) suggested that a longer rumination time would increase the 
possibility that grain would be broken during mastication. The size of the reticulo-omasal orifice in mature sheep seems to be small enough to prevent barley grain escaping from the rumen. This increases the chance of whole grain being broken during rumination.

Increasing the proportion of grain in the diet increased DM digestibility in both hay diets. However, it had no effect on ADF digestibility, which is not in agreement with the results of previous studies (Uden, 1984; Mayne and Gordon, 1985). Uden (1984) suggested that the depresion in fibre digestibility was not linear and started at a level of approximately $30 \%$ concentrates. It is possible that the 25 and $40 \%$ levels of grain in the diet used in the present study were too low to detect an effect. The results obtained indicate that increasing the level of grain to $40 \%$ increased the $\mathrm{N}$ balance only with the grass hay diet. The grass hay quality was low $(6 \% \mathrm{CP})$ and the addition of protein and energy to the rumen probably resulted in more efficient microbial protein synthesis.

The lack of a significant interaction between the physical form of grain and its level in the diet shows that whole barley grain can be effectively utilized irrespective of the concentrate-to-forage ratio. Surprisingly, the proportion of grain voided in faeces was higher at the $25 \%$ level in the diet compared to 40 per cent. This tendency was observed with both types of hay (Table 4). The large variation among ewes did not permit validation of these observations. Other authors have also demonstrated variation among animals (Vipond et al., 1985; Chestnutt, 1990). It is possible that the proportion of grain voidance is a characteristic of individual ewes (Vipond et al., 1985).

\section{CONCLUSIONS}

The results obtained indicate that whole barley grain may be used in practical feeding of mature sheep when fed as a supplement to low or good quality hays. The amount of whole grain in the diet seems to be unimportant.

\section{REFERENCES}

Association of Official Analytical Chemists, 1975. Official Methods of Analysis of the Association of Official Analytical Chemists. 12 th ed. Association of Official Analytical Chemists. Washington, $\mathrm{DC}$

Chestnutt D.M., 1990. Effect of forage type on the digestion of whole barley grain by breeding ewes. Anim. Prod. 51, 583-591

Goering H.K., Van Soest P.J., 1970. Forage fiber analysis. Agric. Handbook 379. U.S.D.A.

Mayne C.S., Gordon F.J., 1985. The effect of concentrate-to-forage ratio on the milk-yield response to supplementary protein. Anim. Prod. 41, 269-279

Mould L.F., Ørskov E.R., Gauld S.A., 1983. Associative effects of mixed feeds. II. The effect of dietary addition of bicarbonate salts on the voluntary intake and digestibility of diets containing various proportions of hay and barley. Anim. Feed Sci. Techn. 10, 31-47

Orr R.J., Treacher T.T., 1984. The effect of concentrate level on the intake of hays by ewes in late 
pregnancy. Anim. Prod. 39, $89-98$

Ørskov E.R., Fraser C., 1975. The effects of processing of barley-based supplements on rumen $\mathrm{pH}$, rate of digestion and voluntary intake of dried grass in sheep. Br. J. Nutr. 34, 493-500

Ørskov E.R., 1981. Recent advances in the understanding of cereal processing for ruminants. In: W. Haresign, D.J.A. Cole (Editors), Recent Advances in Animal Nutrition. Butterworths, London, pp. $258-267$

Steel R.G.D., Torrie J.H., 1960. Principles and Procedures of Statistics. McGraw-Hill Book Co., NY, USA

Tait R.M., Jones L., Mohle L., Kowalski Z.M., 1985. Utilization of whole barley by ewes when fed as a suppiement to hay. Proc. Western Sect., American Soc. Anim. Sci. 36, 486-487

Tait R.M., Beames R.M., 1988. Processing and prescrvation of cereals and protein concentrates. In: E.R. Ørskov (Editor). Feed Science. World Animal Science, B4. Elsevier. Amsterdam-Oxford-New York-Tokyo, pp. 151-175

Toland P.C., 1978. Influence of some digestive processes on the digestion by cattie of cereal grains fed whole. Austr. J. Exp. Agric. Anim. Husb. 18, 29-33

Uden P., 1984. The effect of intake and hay: concentrate ratio upon digestibility and digesta passage. Anim. Feed Sci. Techn. 11, 167-179

Vipond J.E., Hunter E.A., King M.E., 1985. The utilization of whole and rolled cereals by ewes. Anim. Prod. 40, 297-301

\section{STRESZCZENIE}

\section{Wpływ rodzaju siana oraz udziału paszy treściwej w dawce na wykorzystanie całego ziarna jeccmienia przez dorosle owce}

Doświadczenic przeprowadzono na 16 dorosłych owcach rasy Dorset, żywionych dawkami siana 7. traw lub lucerny uzupelnionych 25 lub $40 \%$ dodatkiem jęczmienia w postaci śruty lub całego ziarna. W doświadczeniu badano strawność składników pokarmowych, bilans $\mathbf{N}$, natomiast $\mathrm{u}$ owiec żywionych calym ziarnem oznaczano ponadto ilość ziarna wydalonego $w$ kale. Doświadczenie dwuczynnikowe (udzial $w$ dawce $\times$ postać ziarna) wykonywano $w$ ukladzie powtórzonych kwadratów lacińskich tj. $2 \times(2 \times 2)$, oddzielnie dla każdego siana.

$\mathrm{Z}$ wyjątkiem nieznacznego obniżenia strawności suchej masy i białka przy skarmianiu całego ziarna $w$ dawkach \% sianem $\%$ lucerny, postać ziarna, be\%. względu na jego udział w dawce pokarmowej, nie miala istotnego wpływu na strawność skladników pokarmowych i bilans $\mathrm{N}(\mathrm{P}>0,05)$. Całe ziarno wydalane w kale stanowito od 4,7 do $10,2 \%$ ziarna pobranego, chociaż obserwowano przy tym dużą zmienność pomiędzy owcami.

Wzrost udziału jęczmienia w dawce z 25 do $40 \%$ spowodował wzrost strawności suchej masy $(P<0,01)$, jednakże nic mial wpływu na stawność ADF $(P>0,05)$. Bilans $N$ został poprawiony przez dodatek jęczmienia tylko w przypadku siana $z$ traw.

Uzyskanc wyniki wskazują, że całe ziarno jęczmienia może być wykorzystywane przez doroste owce żywione sianem. 